\title{
THE UTILIZATION OF KINEMASTER APPLICATIONS IN THE MAKING OF MULTIMEDIA BASED TEACHING MATERIALS FOR ENGLISH E-LEARNING IN NEW NORMAL (COVID-19)
}

\author{
Acep Haryudin ${ }^{1}$, Farhan Imanullah ${ }^{2}$ \\ 1,2 IKIP Siliwangi \\ ${ }^{1}$ haryacep@gmail.com, ${ }^{2}$ farhanimanullah182@gmail.com
}

\begin{abstract}
The objectives of this study are; 1) to determine the ability in implementing online learning and multimedia use, 2) to determine the difficulties in online learning and difficulties in providing multimedia-based learning. 3. to assist participant in making multimedia-based learning media with the Kinemaster application. Researchers use descriptive qualitative methods. Respondents in this study were prospective students participating of English Education study program. 62.5\% of respondents when teaching always use multimedia, $25 \%$ sometimes use multimedia in teaching, and $12.5 \%$ rarely use multimedia. Regarding difficulties in class management as much as $50 \%$, in time management $25 \%$ and difficulties in operating software $25 \%$. Other obstacles experienced are; $42.9 \%$ of the obstacles are networking, then $42.9 \%$ of the software application systems are not easy to operate and electrical energy sources $14.3 \%$. The number of respondent $100 \%$ not only know but have also used the kinemaster application in making multimedia-based learning media by $62.5 \%$, and $37.5 \%$ who never used the kinemaster, $62.5 \%$ of respondents said it was easy and $37.5 \%$ still had difficulties,. kinemaster really helps respondents in learning as much as 50\% stated that they were helped, $12.5 \%$ did not feel helped, and $37.5 \%$ stated that it was normal.
\end{abstract}

Keywords: Kinemaster, Multimedia, English Online Learning

\section{INTRODUCTION}

The Covid-19 pandemic forces the world community to define the meaning of life, the purpose of learning and the nature of humanity. So far, humans have been forced to live in fast-paced situations, work without stopping, and pursue economic growth targets in a competitive system. However, the spread of the Corona virus (Covid-19), which has become a major crisis for modern humans, forces us to breathe for a moment, stop from the vortex of the system, and look back at life, family and the social environment in a true sense.

Humans are forced to 'stop' from their routines, to make sense of what they are actually looking for from their lives. Indonesia has a big challenge in handling Covid-19. Of all the aspects that are currently challenging, I concentrate on the educational aspect, which is essential to discuss. The education aspect has become the main concentration to find a solution so that the learning process continues without violating health protocols. The Covid-19 pandemic forces a social distancing policy, or in Indonesia it is more introduced as physical distancing (maintaining physical distance) to minimize the spread of Covid-19. So, this policy is being pursued to slow down the rate of spread of the Corona virus in the community. 
The Ministry of Education and Culture (Kemdikbud) responded with a policy of studying from home, through online learning and this year following the elimination of the National Examination (Pinar, 2009). In line with the government policy for Learning from Home, of course it does not mean without obstacles, including obstacles in terms of internet network infrastructure, both software and hardware, both from the side of teachers, educators and students or students, many students have internet network problems, limited internet quota, do not have gadgets or other adequate facilities, also from the educator's point of view there are still those who cannot take advantage of the IT or platform applications available in online learning, educators today are required to be able to use various online facilities in learning, but if educators are only as application users other learning then it is not enough, in online learning educators must be more creative so that the learning process becomes interesting, therefore educators are required to be able to present and make learning more interesting, one of which is by making multimedia learning media which can later be uploaded to $b$ various social media or other online learning media, so that if there are network constraints during online learning hours, students are expected to be able to access teaching materials or materials at other times, and this will help students to understand the content of the material delivered by educators. Of the many applications for making learning media, one that can be used is Kinemaster, one of the free android / iOS applications with easy-to-practice features.(Adnyana et al., 2020)

The specific objectives of this research are; 1) to determine the ability of PPL participant students in implementing online learning and making multimedia-based teaching materials, 2) to determine the difficulties faced by PPL participant students in online learning and difficulties in providing multimedia-based learning. 3. to assist PPL participant students in making multimedia-based learning media with the Kinemaster application.

\section{Kinemaster}

KineMaster is a mobile application specifically designed to help Android and iOS users modify videos from ordinary videos to more interesting videos. KineMaster itself was launched by a large company called NexStreaming, headquartered in Seoul, Korea and has several branches around the world, such as in the United States, Spain, China and Taiwan.(Adnyana et al., 2020)

\section{a. Interface}

The KineMaster developers seem to have a different perspective in terms of interfaces. So, instead of spending energy on designing interfaces that are not the main element, developers prefer to focus on powerful tools and features. So don't be surprised if the first time you run the KineMaster application, we only find a simple display of four buttons with a background in the form of a large image that looks dominating.

Picture 1. Kinemaster display

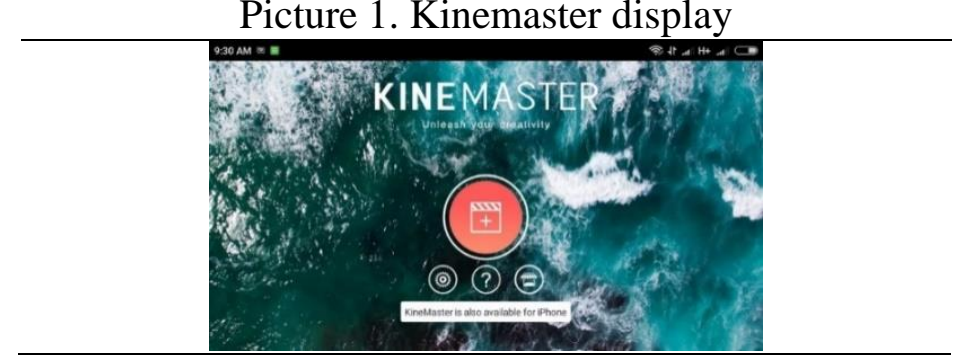

Round red button is the main entrance to discovering the true "inner beauty" of KineMaster. This button will take you to the creation of a new project which will display all the video editing 
tools you need. The other three buttons consist of settings, help and shop buttons. The last menu contains various complementary elements, such as audio, which can later be downloaded as a complement to the projects that are being made. One more thing, when KineMaster runs for the first time, you will immediately be put in landscape mode, including when you open the settings panel.(Winarso, 2018)

\section{b. KineMaster Features}

\section{Project Assistant}

When you first create a project, KineMaster will offer two types of projects, the first is Project Assistant and the second is Empty Project. Both are both together to create new video editing projects, the difference is that Project Assistant offers assistance with a series of systematic video creation processes making it much easier for new users. In Project Assistant, KineMaster will guide us from selecting videos, themes, inserting videos, filters, text and so on until it becomes a beautiful final video.(Fajariyah, 2018)

\section{Multiple Media Support}

Although it doesn't support all types of videos, KineMaster has so far been able to accommodate most of the videos recorded by smartphones. Media input in KineMaster is also fairly easy, even though you can't choose a media source, whether from internal or external memory. All media will be displayed in the same window, but separated by folder and three extra folders including Background, Favorite and Cloud Storage. The rest are folders in the device memory.(Feinberg et al., 2016a)

\section{Theme}

This feature also helps new KineMaster users, where there are four theme choices, including Basic, On-Stage, Serene and Travel.

\section{Text}

Next, KineMaster also offers an option to add text into the video. Text options include an opening and an ending, where each text can be further adjusted by selecting a color and also the type of text that suits the user's taste.(Feinberg et al., 2016b)

\section{Audio}

It's incomplete if a video editing application like KineMaster doesn't have a background sound feature. To differentiate themselves from other applications, KineMaster has a wider range of options, where users can choose the source they feel is most appropriate for them. For example, there is a Music Assets option from the store, then SFX Assets, recordings, songs from device memory, albums, artists and even genres and additional menu folders if the user has a reference from their local device. In addition to offering more complete audio source options, KineMaster also allows users to set how loud the background sound is, how the video first appears and ends, then the viewing duration for photo content types.(Adnyana et al., 2020)

\section{Complete Editing Tool}

Now, take a look at the winning features. In this section, the true abilities of the KineMaster will be revealed. When the video has been inputted, the audio has also been selected and the text has been typed, all the pieces will be gathered together in the main editing window. In this window, there's an awful lot going on. The first time I was in this window, it took me about 30 minutes to understand how it works and what each button does.(Indriani \& Pangaribuan, 2020) 


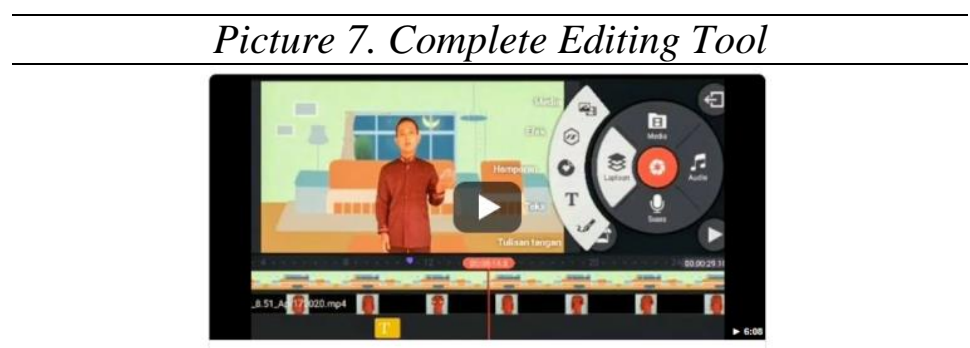

So, there are several features that are found. To make it easier, this will only create a complete list with terms it can understand. The original language may be different.

1. Multiple layer support

2. Voice over

3. Playback

4. Sharing

5. Cut, Copy, Crop

6. Color filters

7. Color adjustment

8. Vignette
9. Trimming

10. Split

11. Rotate

12. Records from cameras and camcorders

13. Drag and Drop

14. Capture frame

15. Duplicate

16. Undo / redo

With KineMaster, young people today who tend to judge things from the first sight may find it difficult to like KineMaster in the early minutes. It was my first time using KineMaster to feel a strong stiff impression. However, that impression faded when entering the main editing window. So, if you are allowed to provide input, it would be great if the KineMaster developer did a makeover on the interface side. How do you make the main interface look beautiful and not stiff. Performance also makes me feel like I am compatible with KineMaster. The file size is fairly light, only $25 \mathrm{MB}$, and the performance as long as I used it on the Redmia $5 \mathrm{~A}$ smartphone, was fairly smooth. (Feinberg et al., 2016b)

\section{c. Sparks}

1. Small file size

2. Smooth performance

3. Very complete features

4. The Project Assistant feature is very helpful for new users

\section{d. Slacks}

1. The interface seems stiff

2. Difficulty changing text size

3. A single media source makes it difficult to select the video file

4. There is no back button in the Project Assistant type, causing doubts when you want to return to the previous process.

\section{Multimedia-based teaching materials}

Teaching materials are all forms of content, including text, audio, photos, videos, and animations that can be used for learning. As part of learning resources, teaching materials have an important role in learning planning and the learning process. Furthermore, it is stated that the teaching material functions as, (1) a guide for teachers / educators who will direct their activities in the learning process, as well as a substance of competencies that should be taught to students / students, (2) guidelines for students / students who will direct all activities in the learning process are at the same time a substance of competence that should be learned / mastered, (3) a tool for evaluating the achievement / mastery of learning outcomes. (Amine et al., 2012) 
In terms of the subject, teaching materials can be categorized into two types, namely teaching materials that are deliberately designed for learning and materials that are not designed but can be used for learning such as clippings, newspapers, films, soap operas, advertisements and news. Because it is not designed, its use as a teaching material needs to be aligned with the learning objectives. Learning materials designed are teaching materials that are deliberately prepared for learning purposes. In terms of function, the designed teaching materials can be grouped into three groups, namely presentation materials, reference materials, and independent study materials. Meanwhile, in terms of teaching material media, teaching materials are grouped into printed teaching materials (hand-out, module), audio, video, television, multimedia, and the web (Yazdi et al., 2012)

Multimedia-based teaching materials are teaching materials that are compiled and developed using ICT tools to process data, including processing, obtaining, compiling, storing, in various ways to produce quality information. Similar to the opinion above, also states that one form of teaching material is audio-visual teaching materials (Gruzd et al., 2016). The characteristics of ICT-based teaching materials include: (1) utilizing the advantages of computers (digital media or network technology), (2) utilizing multimedia technology, so that the learning atmosphere becomes attractive, (3) utilizing electronic technology, where teachers / educators and students / students, students / students and students / students, can be connected anywhere and anytime, (4) use independent teaching materials so that it can be accessed anytime and anywhere if the person concerned needs, (5) make use of data exchange (sharing information ) interactively (Indriani \& Pangaribuan, 2020). The advantages of ICT-based teaching materials are as follows. (1) making concrete concepts that are abstract in nature, (2) can bring objects that are dangerous or difficult to find into the learning environment, (3) facilitate interaction, (4) can display objects that cannot be seen with the naked eye.(Wu \& Tai, 2016)

\section{Online Learning (E-Learning)}

E-learning is distance learning that utilizes computer technology or computer networks or the internet. E-learning can allow learners to learn via computers in their respective places without having to physically go to classes or lectures in class. The electronic learning system is a new way of teaching and learning. E-learning is a basic and logical consequence of the development of information and communication technology. With e-learning, teaching participants (learners or users) do not need to sit nicely in the classroom to listen to every word of an educator directly. E-learning can also shorten the target learning time schedule, and of course save costs that must be incurred by a study program or educational program (Nguyen, 2015)

The term e-learning contains a very broad meaning, so that there are many experts who describe the definition of e-learning from various points of view. Among them:

1. E-learning is a type of teaching and learning that allows the delivery of teaching materials to learners using internet and internet media or other computer network media.

2. E-learning is an educational system that uses electronic applications to support teaching and learning using the internet, computer networks, and stand-alone computers.

3. E-learning enables learners to learn via computers in their respective places without having to physically go to class / lectures in class.

4. E-learning is often understood as a form of web-based learning that can be accessed from the internet on local networks or the internet.

5. E-learning is distance learning that utilizes computer technology and computer networks or the internet.(Hanum, 2013) 


\section{Components of E-learning}

1. E-learning infrastructure: E-learning infrastructure can include personal computers (PCs), computer networks, internet and multimedia equipment.

2. E-learning systems and applications: software systems that virtualize conventional teaching and learning processes. How does class management and material or content creation, discussion forums, assessment systems (report cards), online exam systems and all features related to teaching and learning process management.

3. E-learning content: Content and teaching materials in the e-learning system (learning management system). The content and teaching materials can be in the form of multimedia-based content (content in the form of interactive multimedia) or text-based content (content in the form of text as in ordinary textbooks). (Aydin \& Tasci, 2014)

\section{Resources for Online Learning}

In general, when taking an online degree program you may find resources such as:
1. E-Books;
4. lecture recordings;
2. Journal;
5. Quizzes;
7. Live question and
3. Videos;
6. Discussion forum answer session; and
8. Interview.

The resources offered to you for studying online will depend on the institution you are taking your online program from. Some online learning programs may require you to pre-order physical textbooks by mail, but these are generally removed due to eBooks and online delivery methods only. For institutions that have made the transition to using $100 \%$ online resources, students can expect to learn using a combination of cutting-edge technology resources without the need to travel to attend lectures, exams or live discussion sessions (Bruce \& Systems, 2019) a. E-books, text books \& journals

This written material is an essential resource in nearly every course you will take while studying online. Using the reading list for each course, or at the suggestion of the course instructor, you should dedicate the amount of time you need to read and understand the topics in the literature. The main advantage of using these media (especially eBooks) is the fact that they are fully portable, allowing you to study anywhere from your computer, mobile phone or tablet.

\section{b. Lecture recordings}

An essential way of absorbing large amounts of information in a relatively short time, lectures are a staple of online and campus-based learning. With online learning, you can attend lectures anytime and anywhere as long as there are learning tools available (Yazdi et al., 2012)

\section{c. Interactive session}

The biggest challenge facing online education providers is how to replicate the face-to-face interactions and in-person discussions that institutions on campus can easily provide. The solution is that online degree programs often use a combination of discussion forums and interactive question and answer sessions to give you the interaction with other students and instructors you need.

\section{d. How Will Online Learning Be Delivered?}

Online students often think that their learning resources will be sent via email, or even via other social media. Usually, educators have their own platform that is used in online learning, for example, Zoom, Google Classroom, Edmodo, etc. Learning platforms will vary depending on the software used, but will usually consist of a central online platform that students can access from their personal PC, mobile or tablet One of the main benefits of taking advantage of a fully hosted resource online is endless flexibility. As an online student, you can choose to access course information and complete your assignments at any time. This allows you to fit study 
time around work, family, and other commitments. It also means that students who wish to continue working while studying do not have to put their careers on hold.(Hanum, 2013)

\section{e. How to Assess Online Learning?}

Online learning will continue to be tested regularly throughout their study period to assess their understanding of the course / learning material. For those new to online education, this process can be daunting. But not to worry, Online institutions are seasoned professionals, they will ensure that your assessment is fair, comfortable and designed to help you make the most of your learning experience. Usually exams, quizzes etc. for evaluation and assessment are already available on the platform used.(Aydin \& Tasci, 2014)

\section{f. Individual Assignment}

This is probably the method of assessment that most students experience. For each assignment, you will receive your topic, deadline, and word count. You will be asked to produce structured and reasoned arguments within the boundaries set by your course instructor. (Budhiraja, n.d.)

\section{g. Discussion activities}

Face-to-face discussions between friends and colleagues is something we all do on a daily basis. However, online academic discussion requires a different set of skills, and may not come naturally when you first start your online learning journey. These activities will differ depending on the institution, but your course instructor will usually start each discussion with a question or topic for debate. Students then need to research the topic and post their responses to the assignments that demonstrate their own knowledge and understanding. Often times, you will end up in an argument with ideas and views posted by fellow students.

\section{h. Journal activities}

Like discussion boards, journal activities tend to be specific to online courses. Journal entries are continuous updates that give you the opportunity to reflect back on what you have learned during the period under review, and how you will apply what you have learned in the future. Online learning doesn't take place in the classroom, and journal entries are an easy way for course instructors to understand how you are progressing through the course and if you gain knowledge in the right areas. Unlike other assignments, it is acceptable to use subjective and personal writing styles in journal entries and refer to yourself in the first person.

\section{i. Exam}

While they can be very stressful, exams are the main way to test your learning. Institutions can choose to allow students to complete their exams on their personal computers, in a location of their choosing. Since tutors have no way to supervise virtual exams or exams, they are usually open-book and open-note. As a viable alternative, many institutions will offer the option of completing a 'take-home' exam in the form of an essay or final project. Some institutions may use exam software such as virtual supervisors, or tools to monitor if you visit a new web page.

\section{METHOD}

This research used a descriptive qualitative method that aims to analyze, describe and develop a Multimedia Learning Model with Kinemaster Applications in the English Education study program . The qualitative research method is a research method based on the philosophy of positivism, used to examine the conditions of natural objects (as opposed to experiments) where the researcher is the key instrument, the sampling of data sources is carried out purposively and snowball, techniques collection by triangulation, inductive / qualitative data analysis, and qualitative research results emphasize meaning rather than generalization (Sugiyono, 2016)

Data collection is carried out in two stages: namely, literature / document review and analysis. The data used in this study are primary data and secondary data (Nunan, 2004). Primary and secondary data were obtained directly from respondents (Candidates for English Teachers at 
IKIP Siliwangi) by using online questionnaires. Then compiled and tabulated, then analyzed the phenomena that occur to further draw the research conclusions (Sugiyono, 2014)

\section{RESULTS AND DISCUSSION}

\section{Results}

Based on the data obtained, it can be explained based on several findings in the field using a questionnaire distributed online to respondents, therefore we can see the following results:

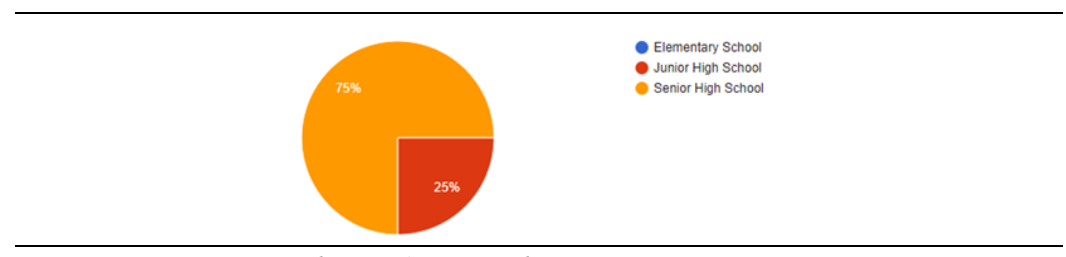

\section{Chart 1. Teaching Experience}

From the data above, the majority of respondents teach at Senior High School as much as 75\% and at the junior high school level as much as $25 \%$ and none of them teach at the elementary level.

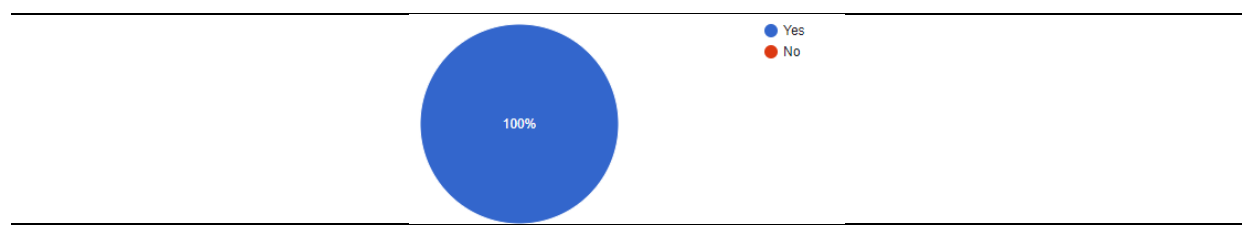

Chart 2. Multimedia-based teaching Acknowledgement

In the results of the questionnaire that all respondents know about multimedia-based learning, as many as $100 \%$ have managed based learning like this.

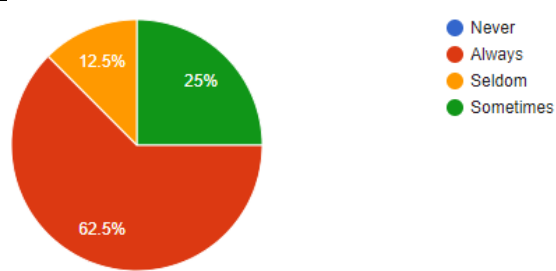

Chart 3. Using multimedia-based teaching materials at online class

In the data presented above, $62.5 \%$ of respondents when teaching always use multi media (video / youtube), $25 \%$ stated that they sometimes use multimedia in teaching, and $12.5 \%$ rarely use multimedia such as videos in learning.

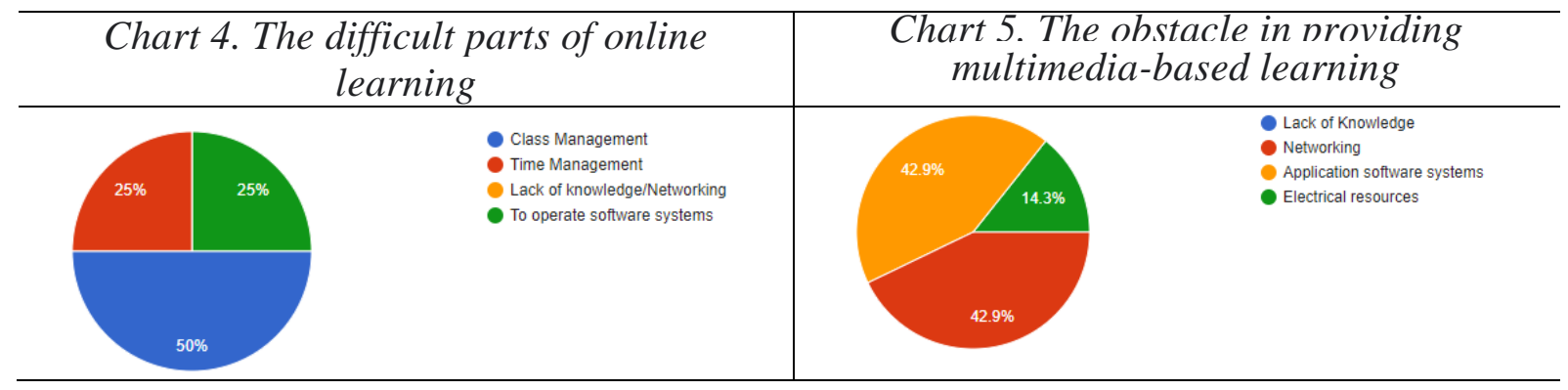


Based on the data on chart 4 regarding difficulties in online learning that at the level of difficulty in online learning, difficulties can be divided into several categories such as difficulties in class management as much as $50 \%$, in time management as much as $25 \%$ and difficulties in operating software as many as $25 \%$. In essence, respondents still have difficulties that must be faced and solutions are found so that online learning runs smoothly.

Other obstacles experienced by respondents as shown in chart 5 in doing online learning are; $42.9 \%$ of the obstacles are networking or network that is often hampered, then $42.9 \%$ of the software application systems are not easy to operate and are not used to it and other device sources such as electrical energy sources that often go out as much as $14.3 \%$ inhibit online learning.

\begin{tabular}{l|l}
\hline Chart 6. Kinemaster Acknowledgement & Chart 7. Ever use Kinemaster to make \\
multimedia
\end{tabular}

From the data above chart 6 , it can be seen that all respondents know the kinemaster application, this is shown by the number of people who know who are in the presentation $100 \%$ knowing. In chart 7 shows that respondents not only know but have also used the kinemaster application in making multimedia-based learning media by $62.5 \%$, and $37.5 \%$ who never used the kinemaster application in making multimedia-based learning media. From these data it also shows that there are still respondents who have never used the Kinemaster application in making multimedia-based learning videos.

\begin{tabular}{c|c}
\hline Chart 8. Kinemaster easy to use & $\begin{array}{c}\text { Chart 9. Kinemaster help to create } \\
\text { multimedia based learning }\end{array}$ \\
\hline
\end{tabular}

On chart 8 shows that kinemater is an easy application to use, does not require special skills, the most important thing is to continue to practice using it, on chart 8 above it can be shown that $62.5 \%$ of respondents said it was easy and $37.5 \%$ still had difficulties, meaning that there were still respondents who stated the inability to operate his kinemaster in making multimedia-based learning media.

On the other hand, on chart 9 shows that actually the kinemaster really helps respondents in learning as much as 50\% stated that they were helped, 12.5\% did not feel helped, and 37.5\% stated that it was normal, from two data that stated that they were not helped and they were normal they were not able to Operate the kinemaster so that it does not appear to be of use to them in making multimedia-based learning media. If they understand how to use it then of course they will gain benefit from kinemaster 


\section{Discussion}

From the research data that there are still participants who do not understand how to use Kinemaster in making multi-media-based learning media, there are also participants who have not used the application, but in the future it is hoped that this application can especially help educators in making learning media so that learning can be done. done via multimedia. 37.5\% still had difficulties, meaning that there were still respondents who stated the inability to operate his kinemaster in making multimedia-based learning media and and $37.5 \%$ who never used the kinemaster application in making multimedia-based learning media.

\section{CONCLUSION}

From the data above, the majority of respondents teach at Senior High School as much as 75\% and at the junior high school level as much as $25 \%$ and none of them teach at the elementary level. In the results of the questionnaire that all respondents know about multimedia-based learning, as many as $100 \%$ have managed based learning like this. In the data presented above, $62.5 \%$ of respondents when teaching always use multi media (video / youtube), $25 \%$ stated that they sometimes use multimedia in teaching, and $12.5 \%$ rarely use multimedia such as videos in learning. Based on the data on chart 4 regarding difficulties in online learning that at the level of difficulty in online learning, difficulties can be divided into several categories such as difficulties in class management as much as $50 \%$, in time management as much as $25 \%$ and difficulties in operating software as many as $25 \%$. In essence, respondents still have difficulties that must be faced and solutions are found so that online learning runs smoothly.

Other obstacles experienced by respondents as shown in chart 5 in doing online learning are; $42.9 \%$ of the obstacles are networking or network that is often hampered, then $42.9 \%$ of the software application systems are not easy to operate and are not used to it and other device sources such as electrical energy sources that often go out as much as $14.3 \%$ inhibit online learning. From the data above chart 6 , it can be seen that all respondents know the kinemaster application, this is shown by the number of people who know who are in the presentation $100 \%$ knowing. In chart 7 shows that respondents not only know but have also used the kinemaster application in making multimedia-based learning media by $62.5 \%$, and $37.5 \%$ who never used the kinemaster application in making multimedia-based learning media. From these data it also shows that there are still respondents who have never used the Kinemaster application in making multimedia-based learning videos. On chart 8 shows that kinemater is an easy application to use, does not require special skills, the most important thing is to continue to practice using it, on chart 8 above it can be shown that $62.5 \%$ of respondents said it was easy and $37.5 \%$ still had difficulties, meaning that there were still respondents who stated the inability to operate his kinemaster in making multimedia-based learning media.

On the other hand, on chart 9 shows that actually the kinemaster really helps respondents in learning as much as 50\% stated that they were helped, $12.5 \%$ did not feel helped, and $37.5 \%$ stated that it was normal, from two data that stated that they were not helped and they were normal they were not able to Operate the kinemaster so that it does not appear to be of use to them in making multimedia-based learning media. If they understand how to use it then of course they will gain benefit from kinemaster 


\section{ACKNOWLEDGMENTS}

This article is based on the results of research outputs that funded by the IKIP Siliwangi internal grant in 2020.

\section{REFERENCES}

Adnyana, P. B., Citrawathi, D. M., Putu, N., \& Ratna, S. (2020). Efektivitas Pelatihan Pembuatan Flipped Classroom Video Dengan Smartphone dan Aplikasi Kinemaster ( PROGRAM PkM ). 1758-1765.

Amine, B. M., Benachaiba, C., \& Guemide, B. (2012). Using Multimedia to Motivate Students in EFL Classrooms: A Case Study of English Master's Students at Jijel University, Algeria. Malaysian Journal of Distance Education, 14(2).

Aydin, C. H., \& Tasci, D. (2014). Measuring Readiness for e-Learning: Reflections from an Emerging Country. Measuring Readiness for e-Learning: Reflections from an Emerging Country Cengiz Hakan Ayd in Deniz Tasci. May.

Bruce, A., \& Systems, U. L. (2019). 12th International Conference Innovation in Language Learning Proceedings (Issue November). https://doi.org/10.26352/DY14

Budhiraja, R., \& Sachdeva, S. (2002, November). E-readiness Assessment. In International Conference on Building Effective e-Governance.

Fajariyah, L. A. (2018). Pembelajaran Teks Report Dengan Proyek "Cerdig” Berbasis KineMaster. Jurnal Didaktika Pendidikan Dasar.

Feinberg, M. A., Song, K. B., \& Lim, I. T. (2016). KineMaster: pro video editing on Android. In ACM SIGGRAPH 2016 Appy Hour (pp. 1-1).

Gruzd, A., Paulin, D., \& Haythornthwaite, C. (2016). Analyzing social media and learning through content and social network analysis: A faceted methodological approach. Journal of Learning Analytics, 3(3), 46-71.

Hanum, N. S. (2013). Keefektifan E-Learning Sebagai Media Pembelajaran ( Studi Evaluasi Model Pembelajaran E-Learning SMK Telkom Sandhy Putra Purwokerto ) The Effectiveness Of E-Learning As Instructional Media ( Evaluation Study Of E-Learning Instructional Model In SMK Telkom . 3, 90-102.

Indriani, E., \& Pangaribuan, T. R. (2020). Efektivitas Penggunaan Media Kinemaster Terhadap Kemampuan Menulis Teks Prosedur Siswa Kelas VII Smp Swasta Muhammadiyah 05 Medan Tahun Pembelajaran 2019/2020. Basastra. https://doi.org/10.24114/bss.v9i2.19690

Nguyen, T. (2015). The Effectiveness of Online Learning: Beyond No Significant Difference and Future Horizons. MERLOT Journal of Online Learning and Teaching.

Nunan, D. (2004). Task-Based Language Teaching. In Task-Based Language Teaching. https://doi.org/10.1017/cbo9780511667336

Pinar, W. F. (2009). The unaddressed 'I'of ideology critique. Power and Education, 1(2), $189-200$.

Sugiyono. (2014). Metode Penelitian Pendidikan pendekatan Kuantitatif, Kualitatif dan R\&D. In Metode Penelitian Ilmiah.

Sugiyono. (2016). Memahami Penelitian Kualitatif. Bandung: Alfabeta.

Winarso, B. (2018). [Review App] Bikin Video Keren di Smartphone dengan KineMaster Pro Video Editor. 22 May.

Wu, T. J., \& Tai, Y. N. (2016). Effects of multimedia information technology integrated MultiSensory instruction on students' learning motivation and outcome. Eurasia Journal of Mathematics, Science and Technology Education. https://doi.org/10.12973/eurasia.2016.1552a 
Yazdi, M. (2012). E-learning sebagai media pembelajaran interaktif berbasis teknologi informasi. Jurnal ilmiah foristek, 2(1). 